\title{
Historic salt mines in Wieliczka and Bochnia
}

\author{
Zabytkowe kopalnie soli w Wieliczce i Bochni
}

\author{
Janusz Wiewiórka ${ }^{1}$, Józef Charkot ${ }^{2}$, Krzysztof Dudek $^{3}$ \& Małgorzata Gonera ${ }^{4}$ \\ ${ }^{1}$ Retired geologist of the Wieliczka and Bochnia Salt Mines, Park Kingi 5, 32-020 Wieliczka \\ ${ }^{2}$ Cracow Saltworks Museum Wieliczka, Zamkowa 8, 32-020 Wieliczka, e-mail: j.charkot@interia.pl \\ ${ }^{3}$ Faculty of Geology, Geophysics and Environmental Protection, AGH University of Science and Technology, \\ Al. Mickiewicza 30,30-059 Kraków,e-mail: kadudek@agh.edu.pl \\ ${ }^{4}$ Nature Conservation Institute, Polish Academy of Sciences, Al. Mickiewicza 33, 31-120 Kraków, e-mail: gonera@iop.krakow.pl
}
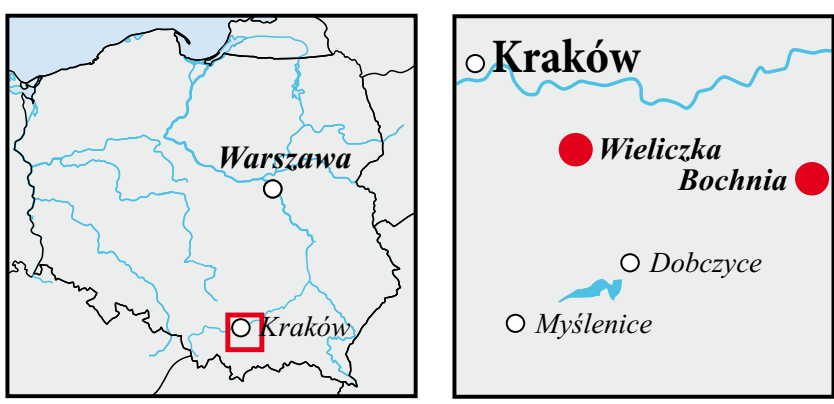

Abstract: Historic salt mines in Wieliczka and Bochnia are situated by the old trade road from Krakow to the east, in the region well known from salt-making from brines since the Neolith (ca. 3500 BC). In Bochnia the rock salt was discovered in 1248, whereas in Wieliczka production of the rock salt was confirmed in the town charter in 1290. At the end of the 13th century both mines were united into the Kraków Saltworks. In the 16th century it was the biggest production centre in Poland and one of the biggest in Europe. The rock-salt exploitation ended in Bochnia in 1990 and in Wieliczka in 1996. Both deposits are situated within the Miocene (Badenian - M4) folded strata of the salt-bearing complex, consisting of the Skawina Formation (at the bottom), the Wieliczka Formation (containing the evaporites), and the Chodenice beds (at the top). The Wieliczka deposit consists of the upper boulder deposit and the lower stratiform one. The boulder deposit was formed as a result of submarine flows in southern part of the evaporite basin. Both the boulder and the stratiform deposits were finally shaped by the overthrust movements of the Outer Carpathians. The Bochnia deposit is limited to the northern limb of the Bochnia anticline, at the northern edge of the Outer Carpathians. The Wieliczka Salt Mine is written into the first UNESCO List of the World Cultural and Natural Heritage (1978) and recognised as a National Monument of History (1994). Since 2000 the Bochnia Salt Mine is the National Monument of History as well. In 1997 the Matopolska voivode issued a decree comprising legal protection of 40 documentated sites, important for geology of the Wieliczka deposit, and in 2000 the Natural Reserve "Crystal Caves" in Wieliczka was established. In 2005, twenty seven documentated sites were established and provided with legal protection in the Bochnia Salt Mine.

Key words: salt mine, Wieliczka, Bochnia, natural heritage, geotourism

Treść: Zabytkowe kopalnie soli w Wieliczce i Bochni znajduja sie przy starym trakcie handlowym z Krakowa na wschód, $w$ rejonie znanym $z$ warzenia soli jeszcze $w$ neolicie (ok. 3500 lat p.n.e.). W Bochni sól kamiennq odkryto w 1248 roku, podczas gdy $w$ Wieliczce wydobycie soli kamiennej jest wzmiankowane wakcie lokacyjnym miasta z 1290 roku. Pod koniec XIII wieku obydwie kopalnie zostały połaczone wjedno królewskie przedsiębiorstwo-
- Krakowskie Żupy Solne. WXVI wieku byt to największy ośrodek produkcyjny w Polsce i jeden z największych w Europie. Wydobycie soli kamiennej zakończyło się $w$ Bochni $w$ 1990, a w Wieliczce w 1996 roku. Obydwa złoża znajduja się w utworach sfatdowanego miocenu (baden-M4) jednostki zglobickiej Karpat zewnętrznych. Seria solonośna składa się z formacji skawińskiej, wielickiej (ewaporaty) $i$ warstw chodenickich. Złoże solne Wieliczki zbudowane jest $z$ górnego złoża bryłowego i dolnego pokładowego. Złoże brytowe zostało utworzone w wyniku podmorskich spływów w południowej części basenu ewaporacyjnego. Obydwie części złoż a zostaty ostatecznie uformowane w wyniku ruchów nasuwczych Karpat. Złoże soli Bochnia znajduje się w pótnocnym skrzydle antykliny Bochni, na pólnoc od brzegu Karpat. W 1978 roku Kopalnia Soli Wieliczka została wpisana na pierwsza listę Światowego Dziedzictwa Kulturowego i Przyrodniczego UNESCO, a w 1994 roku uznana za Narodowy Pomnik Historii. Od 2000 roku Kopalnia Soli Bochnia jest również Narodowym Pomnikiem Historii. W 1997 roku dekretem wojewody małopolskiego objęto ochrona prawnq, w formie stanowisk dokumentacyjnych, 40 obiektów geologicznych w Kopalni Soli Wieliczka, a w 2000 roku ustanowiono rezerwat przyrody ,Groty Kryształowe” w Wieliczce. W 2005 roku ochrona prawnq objęto równiez 27 stanowisk dokumentacyjnych w Kopalni Soli Bochnia.

Słowa kluczowe: kopalnia soli, Wieliczka, Bochnia, dziedzictwo przyrodnicze, geoturystyka

\section{Introduction}

Historic salt mines in Wieliczka and Bochnia are situated by the old trade road extending from Kraków, the old capital of Poland, as far eastwards as to Ukraine (Fig. 1). In the mid13th century rock salt was discovered in the Miocene marine deposits, in close proximity to the edge of the Outer (Flysch) Carpathians. Earlier the region was well known from the occurrence of salt brines, having been used for salt-making since the Neolithic times; ca. 3500 BC (Jodłowski et al., 1988). During more than 700 years of salt exploitation both mines became famous not only for salt but also for historic shafts, galleries and chambers, old mining techniques, tradition and art, as well as for unique geological features. Especially now, when the salt exploitation is over and the mines are partly backfilled and abandoned, historic galleries and chambers are like open pages of the Earth's history, fascinating not only geology professionals and students, but hundreds of thousands of tourists as well. Therefore, both Wieliczka and Bochnia Salt Mines are important elements of the planned Starunia (Ukraine) - Kraków (Poland) trans-border geotourist trail 'Traces of large extinct mammals, earth wax, oil and salt' (Kotarba, 2009). 


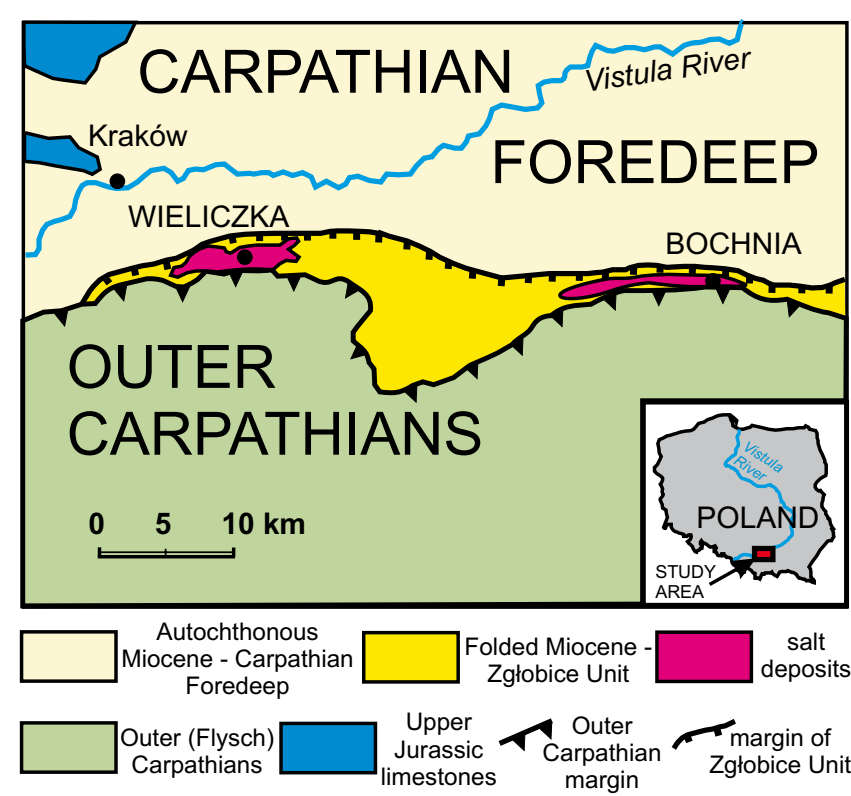

Fig. 1. Structural sketch-map of the Carpathian Foredeep showing the location of Wieliczka and Bochnia salt mines - Szkic strukturalny zapadliska przedkarpackiego z lokalizacją kopalń soli w Wieliczce i Bochni

\section{Mining history}

Historic documents point to the discovery of rock salt in Bochnia, a site known from earlier production of salt evaporated from salt brines, in 1248 (Jodłowski et al., 1988). This significant fact presumably triggered granting a town charter to the settlement in 1253, only five years after starting the salt mining. Wieliczka, however, well known since the 12th century for production of the evaporated salt, is lacking any document that could confirm the discovery of the salt. The production of large cylindrical blocks of salt (like barrels, easy to roll, so-called in Polish bałwany) was mentioned in the town charter, issued by the prince Przemysław II in 1290; hence the discovery and beginning of the rock-salt mining in Wieliczka had to have taken place earlier.

Fast development of the rock-salt mining resulted in uniting both mines into one royal enterprise, the Kraków Saltworks (Polish name Krakowskie Żupy Solne), at the end of the 13th century. This was aimed at increasing the efficiency of the mining works as well as growth of the production of both rock and evaporated salt. In 1368 King Kazimierz the Great, recognising the economic importance of the Kraków Saltworks, granted a modern mining law which became the base for further dynamic development. In the 16th century the Kraków Saltworks while employing about 2000 workers was the biggest production centre in Poland and one of the biggest in Europe. During that time, the rock salt output was similar in both mines, however, by the end of the 16th century Wieliczka substantially prevailed over Bochnia in salt production (Jodłowski et al., 1988). This was due to the more difficult mining conditions in Bochnia, related to the geological position of the narrow and steeply plunging deposit.

The existence of the Kraków Saltworks in Old Poland ended with the annexation of the whole region by Austria in 1772. The Austrian administration modernised the mines and improved the exploitation, and gained considerable profits from the salt mining in Wieliczka and Bochnia. The Austrian liquidation of the Kraków Saltworks resulted in the formation of two independent mining enterprises, which functioned in Poland after 1918, and also during the German occupation (1939-1945), and in the time of Peoples' Republic of Poland (1945-1989). A short episode referring to the idea of the Kraków Saltworks took place in 1970-1980, when a single enterprise, the Salt Mines Wieliczka-Bochnia was created. In 1980 the mines were separated once more.

A period of over 700-years of salt exploitation came to an end - in Bochnia in 1990, and in Wieliczka in 1996. Even before the end of production, securing and protection of the historic parts of the mines had begun in conjunction with the liquidation of unnecessary underground excavations and industrial devices on the surface.

Already in the Renaissance times occasional touring of the dangerous, but interesting underground chambers and galleries by visitors had begun. These visitors were guests of the Royal Court or the officers managing the Kraków Saltworks. The first reported tours took place at the Wieliczka Salt Mine, which is closer to Kraków and was more easily accessible. An interesting document, confirming a tourist expedition to Wieliczka and Bochnia in the Renaissance Age, is the report of an outstanding Swiss humanist, Joachim von Watt (Vadianus), who toured the mines in 1518 (Smaron, 1982). In 1760 the mine in Wieliczka was visited by a French naturalist Jean -Etienne Guettard, the author of the first geological map of Poland (Wójcik, 1977; Tarkowski, 2005). The Wieliczka Salt Mine became a renown tourist site at the end of the 18th century, when in 1790 it was visited by Stanisław Staszic and Johann Wolfgang Goethe. Recent dynamic development of tourism, underground health care, various social and even political events, as well as dedicated tours (geology, geotourism) created for the historic mines an excellent opportunity for further activity and development.

\section{Geological background}

The marine Miocene strata, containing the evaporite series with the rock salt, occur in southern Poland in the Carpathian Foredeep, a vast geological unit stretching around the Outer (Flysch) Carpathians from the Danube near Vienna (Austria) in the south-west, through Slovakia, Czech Republic, Poland, and Ukraine, to the Iron Gate (Romania) in the south-east. The Carpathian Foredeep was exhaustively presented in numerous papers, e.g. by Oszczypko (1996, 1997), Andreyeva-Grigorovich et al. (2003), Oszczypko et al. (2006). The thickness of the evaporite series, mainly consisting of clays, mudstones, sandstones, and the evaporites, increases from west to east, from a few hundred up to $3000 \mathrm{~m}$ (Garlicki, 1979). In the stratigraphical column the evaporite series (Wieliczka Formation) is underlain by the Skawina Formation and overlaid by the Chodenice beds, formally included into the Machów Formation (Alexandrowicz et al., 1982; Garlicki, 1994). In the southern part of the Carpathian Foredeep, the Miocene (Badenian - M4) sediments are strongly disturbed by the orogenic movements of the Outer Carpathians, forming the so-called allochtho- 
nous series (unit) or the Zgłobice Unit (Oszczypko, 1997). Since both mines exploited the rock salt deposits in the allochthonous unit, the primary thickness of the salt-bearing series could be learned only from the undisturbed, autochthonous unit, north of the folded sediments.

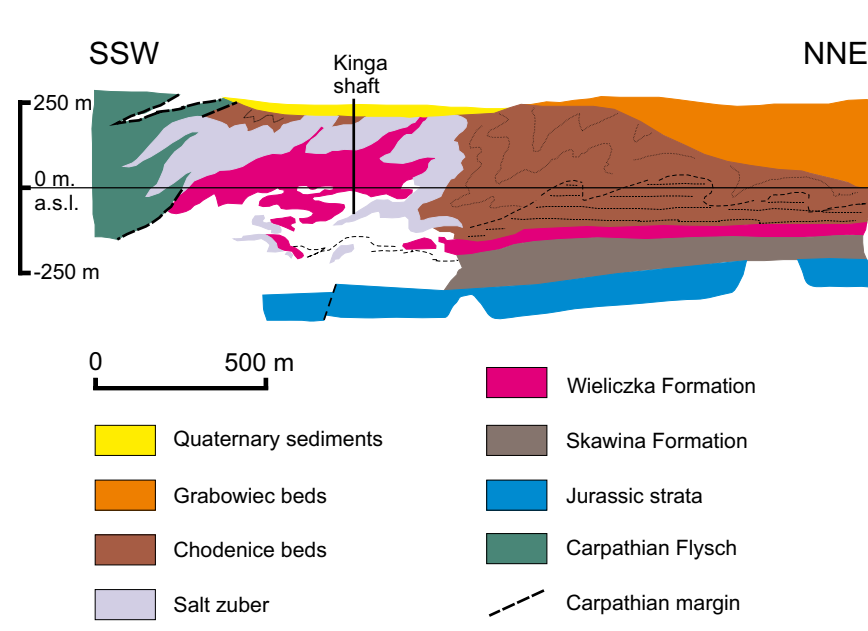

Fig. 2. Geological cross-section of the Wieliczka deposit (after Garlicki, 1968, 2008, simplified) • Przekrój geologiczny przez złoże Wieliczka (wg Garlicki, 1968, 2008, uproszczony)

\section{Wieliczka Salt Mine}

In the vicinity of Wieliczka, the sediments of the Skawina Formation are lying on the eroded surface of the Upper Jurassic limestones of the Mesozoic Basement. The thickness and lithological character of the Skawina Formation change from west to east. In the west, near Barycz, where the thickness is ca. $45 \mathrm{~m}$, they occur as greenish-grey marly clays, with ubiquitous foraminifers, often mineralised with pyrite (Gonera, 2001). Near the St. Kinga shaft the thickness of the Skawina Formation increases to about $150 \mathrm{~m}$, with a corresponding increase in the sand content. In the eastern part of the Wieliczka deposit, where mudstones and sandstones prevail, the formation reaches a thickness of $350 \mathrm{~m}$ (Wiewiórka, 1988). Close to the top of the Skawina Formation, a layer of the amphibole tuff WT-1 was recognised in the eastern part of the Wieliczka Salt Mine (Wiewiórka, 1979).

The Wieliczka Formation (evaporate series) consists of the rock salt together with the siliciclastic (clays and sandstones) and sulphate (gypsum and anhydrite) sediments. The Wieliczka rock-salt deposit (Fig. 2) stretches East - West in a belt about $10 \mathrm{~km}$ long and about 300-1000 $\mathrm{m}$ wide. The centre of Wieliczka Formation, and the deposit optimum, is situated about $14 \mathrm{~km}$ SE of Kraków, in the area of the historic settlement.

\section{Boulder deposit}

Top sandstone and
clays with anhydrite

Upper spiza salts

Clays with anhydrite

Lower spiza salts

Shaft salt

Green salts and clays with anhydrite

Clays with anhydrite

Mid-salt sandstone

Oldest salts

Bottom layers
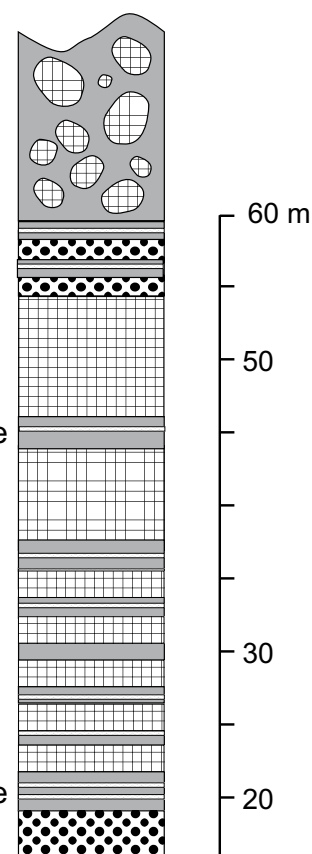

50

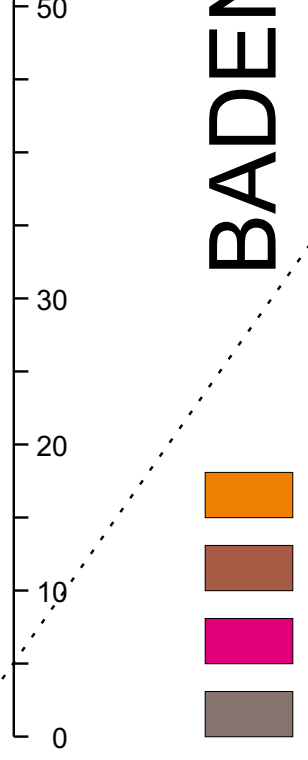

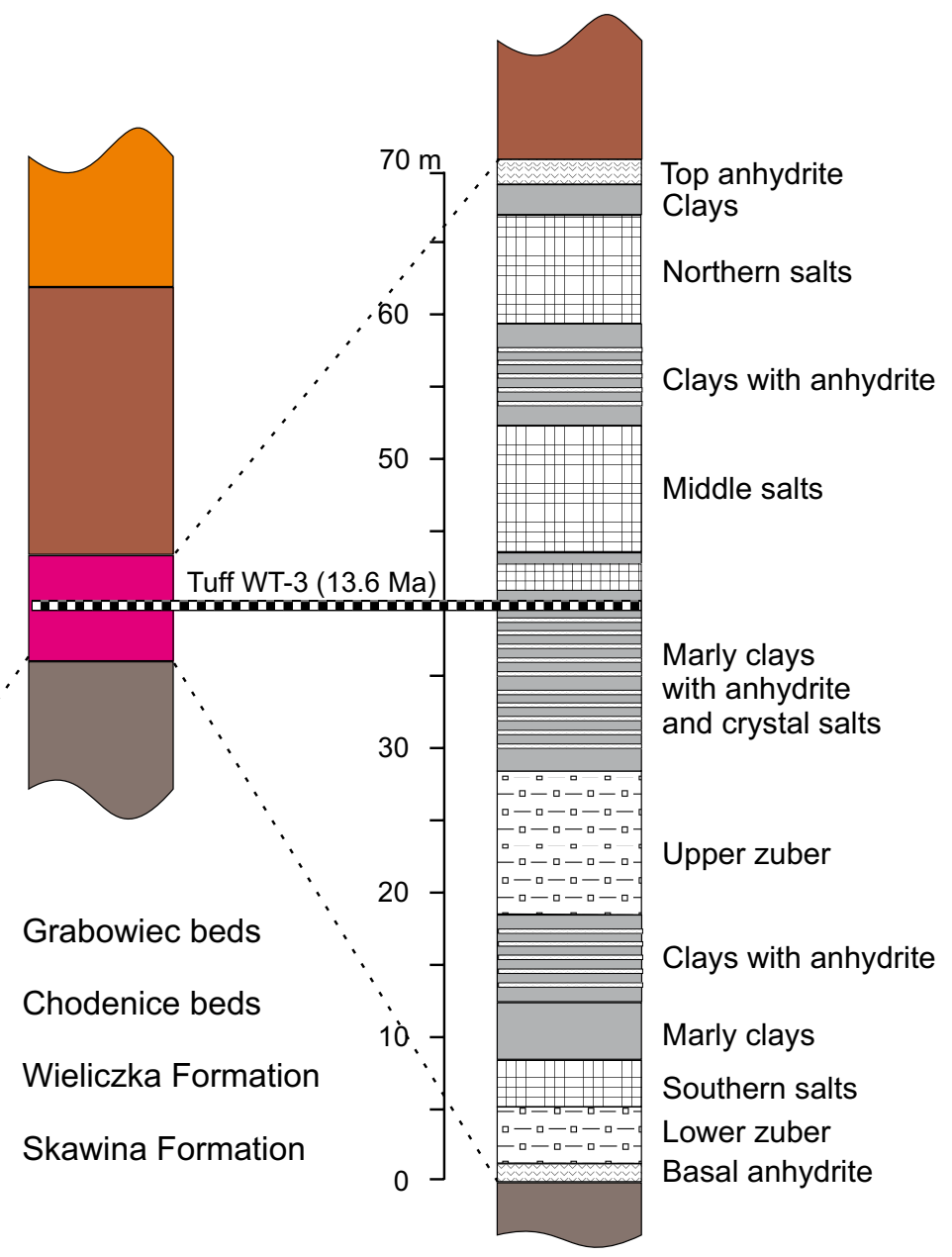

Fig. 3. Stratigraphical profiles of the Wieliczka (left) and Bochnia (right) salt deposits (compiled after Poborski, 1952, Gawel, 1962, Wiewiórka, 1988, Bukowski 1999, Wiewiórka et al., 2009) • Profile stratygraficzne złóż soli Wieliczka (z lewej) i Bochnia (z prawej) (zestawione wg Poborski, 1952, Gaweł, 1962, Wiewiórka, 1988, Bukowski 1999, Wiewiórka et al., 2009) 


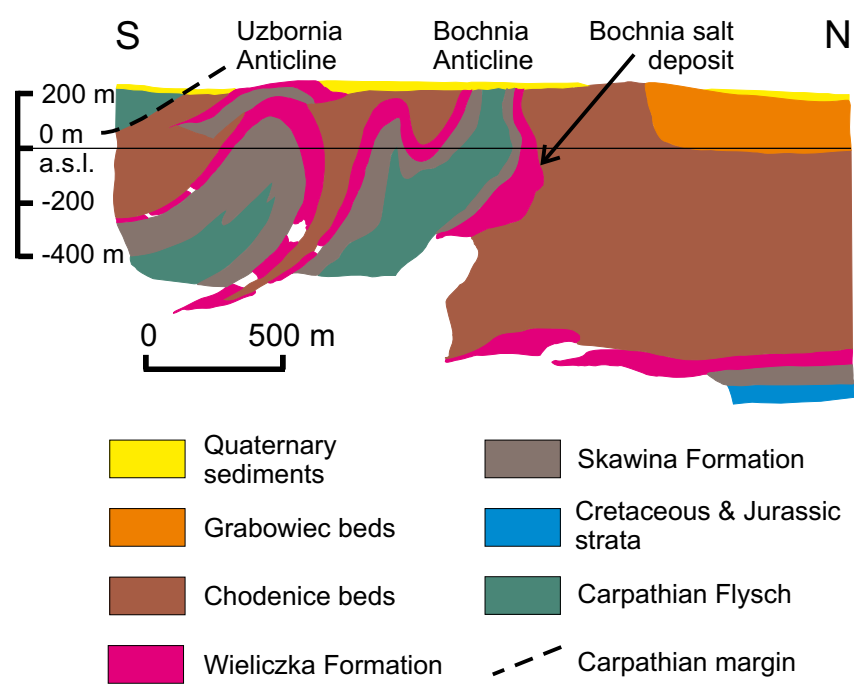

Fig. 4. Geological cross-section of the Bochnia deposit (after Poborski, 1952, Garlicki, 2008, simplified) • Przekrój geologiczny przez złoże Bochnia (wg Poborski, 1952; Garlicki, 2008, uproszczony)

In that place, where the salt series was squeezed towards the surface, the rock salt is lying at about $20 \mathrm{~m}$ depth, beneath the Pleistocene clays and clay-gypsum cover. The discovery of the rock salt presumably took place in the area of the northern outcrops of the deposit, in the vicinity of brines naturally flowing out of porous and water-saturated sandstones of the Chodenice beds.

The Wieliczka deposit is distinguished from other salt deposits in the world by its peculiar division into the upper, boulder (olistostrome) deposit, and the lower, stratified one, each of which had great economic importance in over 700year mining history. The Wieliczka Salt Mine owes the uniqueness of its underground mostly to the boulder deposit, comprised of salt blocks of various dimensions, intermingled with marly clays and salt zuber (Gaweł, 1962). The salt zuber consists of marly clays with dispersed monocrystalline halite and nodular concentrations of blue anhydrite. The boulder deposit, formed in multiple stages, is a result of both the overthrust tectonics of the Outer Carpathians and the lack of stability of the sedimentary basin bottom (Kolasa \& Ślączka, $1985 \mathrm{a}, \mathrm{b})$. In the southern part of the basin, submarine flows brought about the formation of a mighty olistostrome, composed of green-salt olistoliths and clays of the Skawina Formation, detached from the basement, all stuck in a matrix of the salt zuber. The olistostrome of the boulder deposit was later overthrust onto the sediments of the central facies of the evaporite basin, i.e. on the top of the stratiform deposit. After all, the deposit formed due to a successive overthrust phase, in which both parts were pushed farther to the north and folded into three major scale folds of the stratiform deposit, surrounded by the boulder deposit. These folds (the southern, central, and northern ones) are best observed in the middle part of the deposit, between the Kościuszko, St. Kinga, Daniłowicz, and Regis shafts. The stratiform deposit, though strongly disturbed, retained the original succession of the layers, enabling the reconstruction of the lithostratigraphical profile (Gaweł, 1962; Wiewiórka, 1974) as follows, from the oldest layers to the youngest ones (Fig. 3):

- the bottom layers (lying on the top of the Skawina Formation), consisting of clays and sandstones with gypsum and anhydrite, of 2-3 $\mathrm{m}$ in thickness;

- the oldest salts, of ca. $10 \mathrm{~m}$ in thickness and considerable variability in lithology as well as occurrence in the stratiform deposit (Wiewiórka, 1974; Charysz \& Wiewiórka, 1976);

- the mid-salt (formerly sub-salt) sandstone forming, together with anhydrite clay at the top and tuff layers WT-2 and WT-3 (Wiewiórka, 1979), a barren complex separating the oldest salts from the sediments of the higher, large salt cyclothem, containing earlier known salts of the stratiform deposit; the thickness of the mid-salt sandstone amounts to $4-10 \mathrm{~m}$;

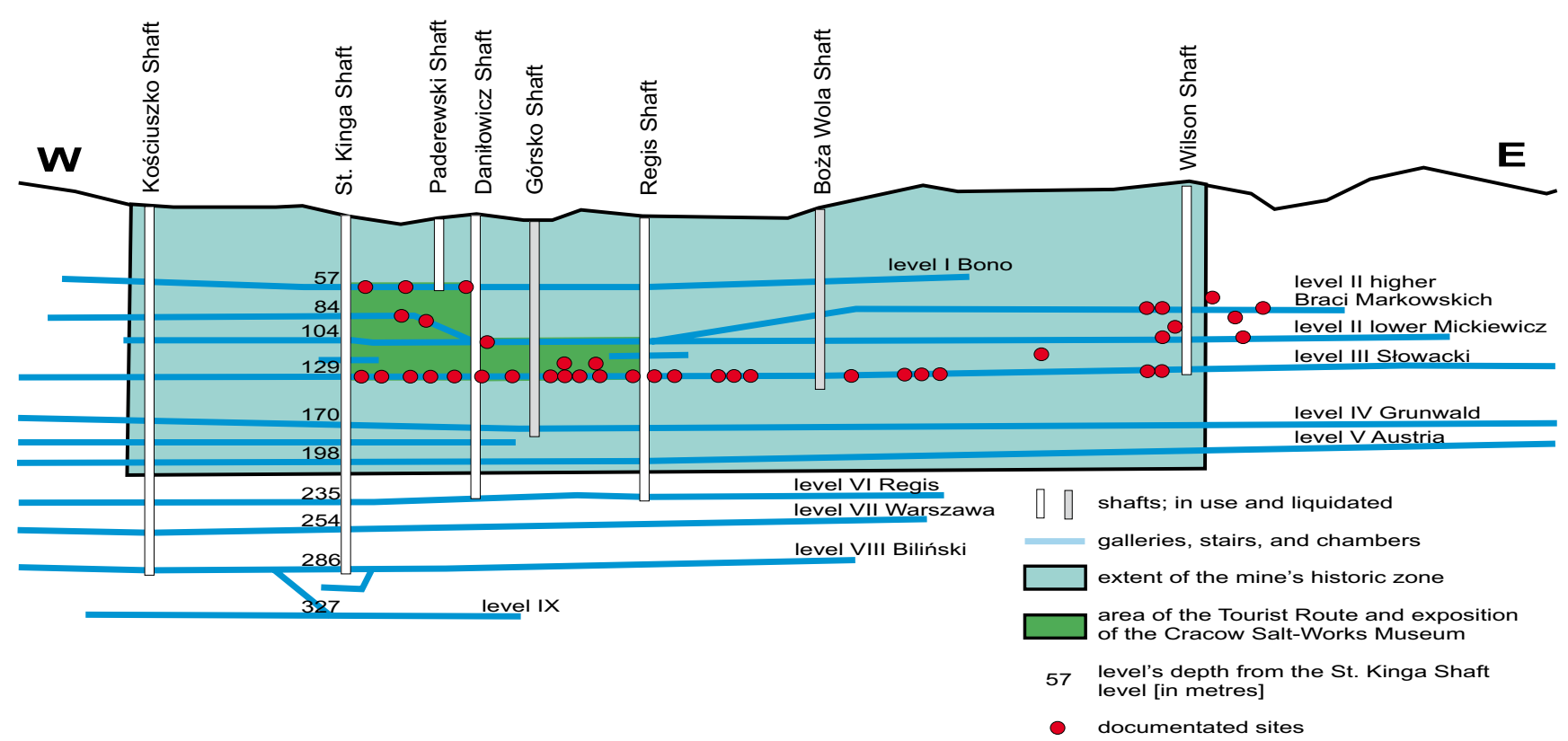

Fig. 5. Vertical sketch-map of the Wieliczka Salt Mine with the documentated sites • Pionowy szkic Kopalni Soli Wieliczka ze stanowiskami dokumentacyjnymi 
- a complex of the layered green salts, encompassing four layers of the coarse-grained (crystal) salt, separated with barren intercalations of clay with anhydrite; the thickness of the complex varies from a few up to twelve metres;

- the layer of the shaft salt, of the average thickness of ca. 2 $\mathrm{m}$ and $\mathrm{NaCl}$ contents of ca. $99 \%$, the most widely stretching salt layer and economically the richest part of the whole stratiform deposit;

- a complex of the spiza salts, the highest occurrence of the rock salt in the lithostratigraphical column of the stratiform deposit, structurally highly variable, with numerous intercalations of barren sediments, ubiquitous fossilised animals and carbonised Miocene plants, of the thickness varying between 10 and $20 \mathrm{~m}$, the thickest barren layer, called the central layer, divides the spiza salts into the lower and the upper ones;

- the top sandstone and clay with anhydrite, ca. 6-8 $\mathrm{m}$ in thickness, mark the end of sedimentation of the Wieliczka Formation.

The evaporite series is followed in the lithostratigraphical column by the Chodenice beds. In the vicinity of Wieliczka they consist of layered marly clays with inserts of unconsolidated mudstones, sandstones and dolomitic marls, relatively hard, indicating the end of evaporite sedimentation. In the zone directly north of the salt-deposit border, the Chodenice beds, however, appear as strongly water-saturated sandstones, conglomerates and breccias, presenting a great risk of uncontrolled water inflows into the underground galleries and chambers of the historic mine.

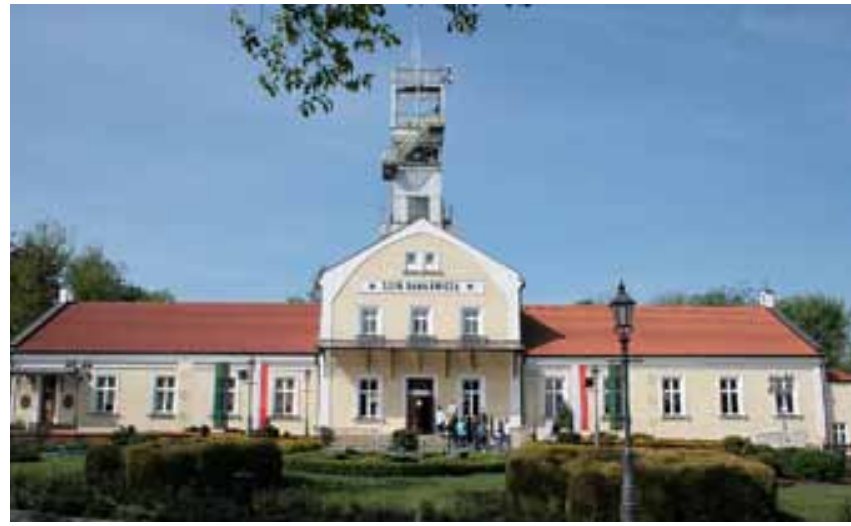

Fig 6. The Daniłowicz Shaft of the Wieliczka Salt Mine. Phot. A. Grzybowski • Szyb Daniłowicza Kopalni Soli Wieliczka. Fot. A. Grzybowski

The Grabowiec beds, appearing farther to the north of the deposit border and representing the youngest marine Badenian deposits in the area, deposited on the earlier folded salt-bearing series. In the vicinity of Wieliczka they are well known as the Bogucice sands.

\section{Bochnia Salt Mine}

In the vicinity of Bochnia the salt-bearing series was recognised in the underground and surface outcrops as well as in numerous boreholes. Its primary thickness was established on the basis of drilling done in the autochthonous part, situ-

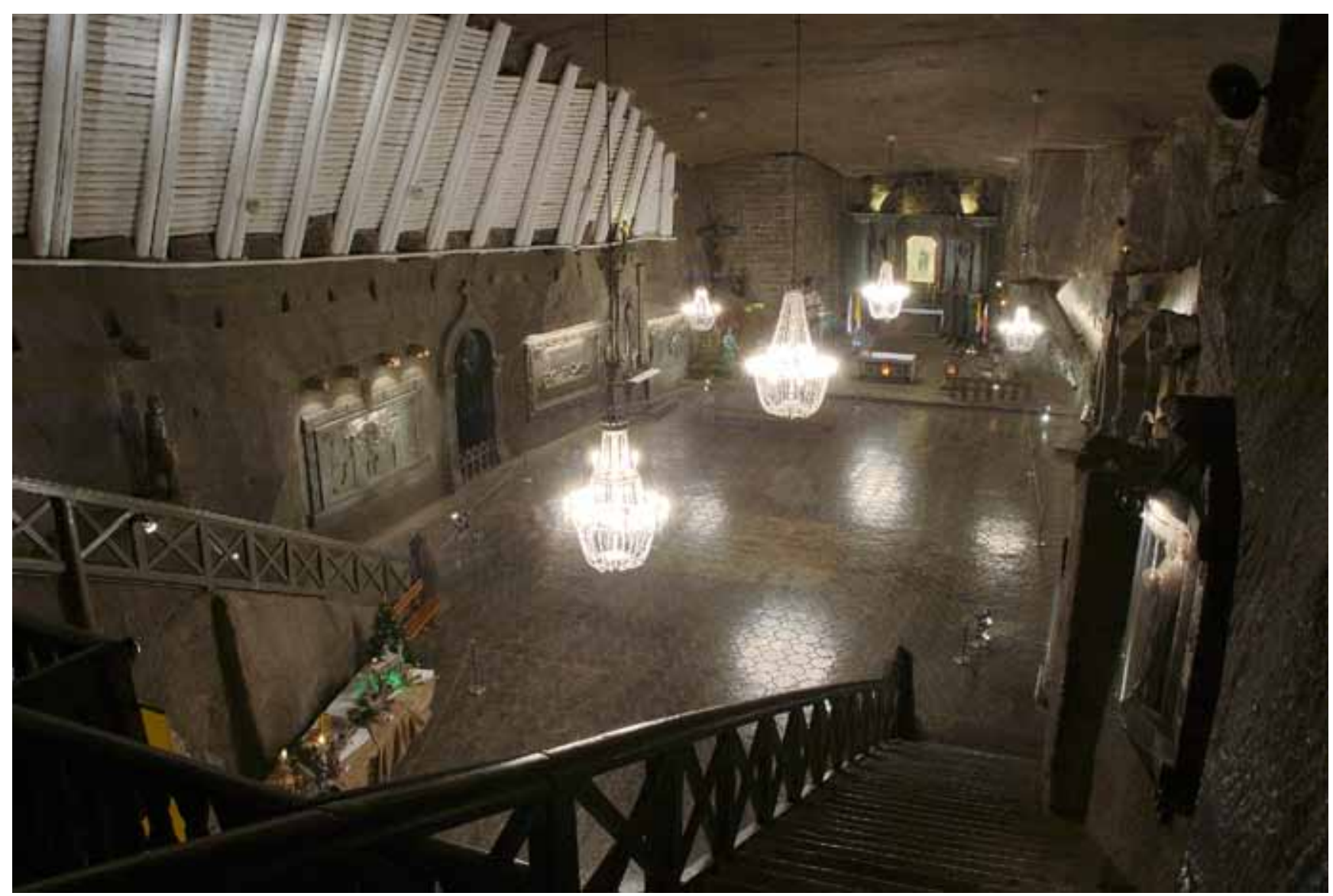

Fig. 7. St. Kinga Chapel in the Wieliczka Salt Mine. Phot. A. Grzybowski • Kaplica Św. Kingi w Kopalni Soli Wieliczka. Fot. A. Grzybowski 


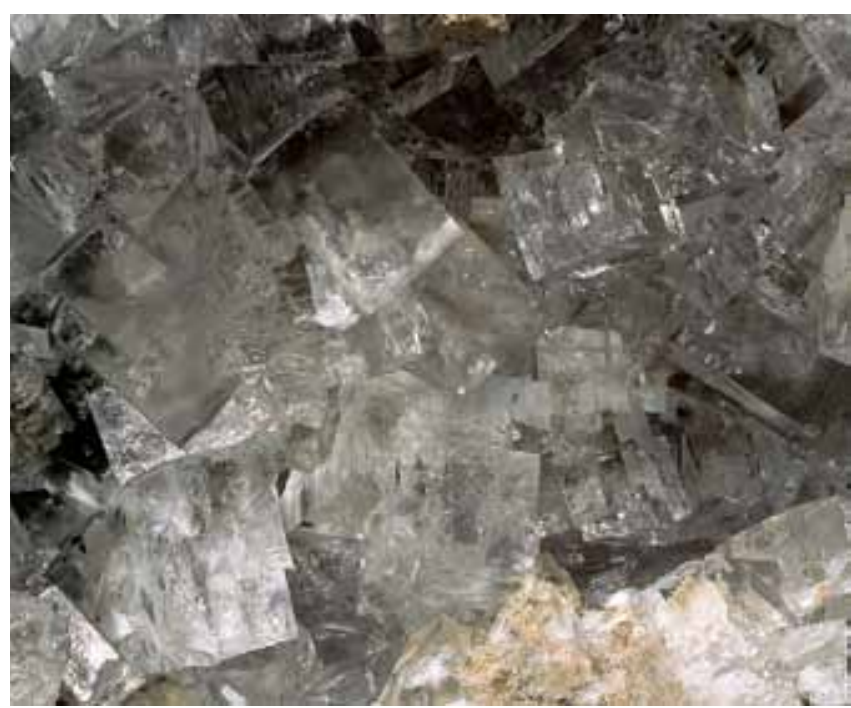

Fig. 8. Halite crystals in Crystal Caves in the Wieliczka Salt Mine. Phot. A. Grzybowski • Kryształy halitu w Grotach Kryształowych w Kopalni Soli Wieliczka. Fot. A. Grzybowski

ated north of the strongly deformed allochthonous sediments. Autochthonous salt-bearing series is lying on a basement of the Jurassic and Cretaceous carbonate rocks.

The Skawina Formation, ca. $100 \mathrm{~m}$ in thickness, consists of marly clays with ubiquitous foraminifers. In the chambers and galleries of the mine it outlines the southern border of the deposit, and also appear as olistoliths in olistostromea (Wiewiórka et al., 2007).

The Wieliczka Formation consists of marly clays and sandstones, dolomitic marls, gypsum and anhydrite, as well as concentrations of the rock salt. The evaporites are divided into five sedimentary cycles (cyclothems) of ca. $70 \mathrm{~m}$ total thickness (Poborski, 1952; Garlicki, 1968). The allochthono- us deposit of Bochnia (Fig. 4), just in front of the Carpathians' margin, is situated in the northern limb of the Bochnia anticline. The evaporites appearing there have been divided into the following lithostratigraphical elements (Fig. 3): basal anhydrite, lower zuber and southern salts, marly clays, clays with anhydrite, upper zuber with rock salt blocks, clays with anhydrite and intercalations of crystal salt, middle salts, clays with anhydrite, northern salts, clays, and top anhydrite (Poborski, 1952).

The Chodenice beds, deposited above the top anhydrite, consist of layered marly clays, separated with dust laminae and inserts of hard dolomitic marls. The thickness of the Chodenice beds amounts to ca. $500 \mathrm{~m}$. Within the entire profile of the salt-bearing complex, similar to that in the vicinity of Wieliczka, several tuff layers appear (Parachoniak, 1962; Dudek et al., 2004).

The Chodenice beds, representing the end of salt sedimentation, are followed in the lithostratigraphical column by the Grabowiec beds - the youngest Badenian sediments in the region. Composed of sands, poorly cemented sandstones and clays, they lie discordantly above the top of the Chodenice beds (Poborski, 1952).

The Bochnia rock-salt deposit, stretching East - West, ca. $4.5 \mathrm{~km}$ in length, is in its upper part almost vertical. At the top, where the salt was eroded, a clay-gypsum crust formed, covered with Pleistocene sediments, mostly loess and clays. The Bochnia deposit is thickest at a depth of 200-400 metres, where it reaches $200 \mathrm{~m}$ in thickness (North - South). That zone is a result of peculiar tectonic enrichment of the rock-salt layers, which were internally folded within larger-scale overthrust folds. Unlike the plastic salt, the more rigid layers of marly clays and anhydrite are frequently fractured, torn and displaced, the fissures having been filled with secondary anhydrite and fibrous halite.

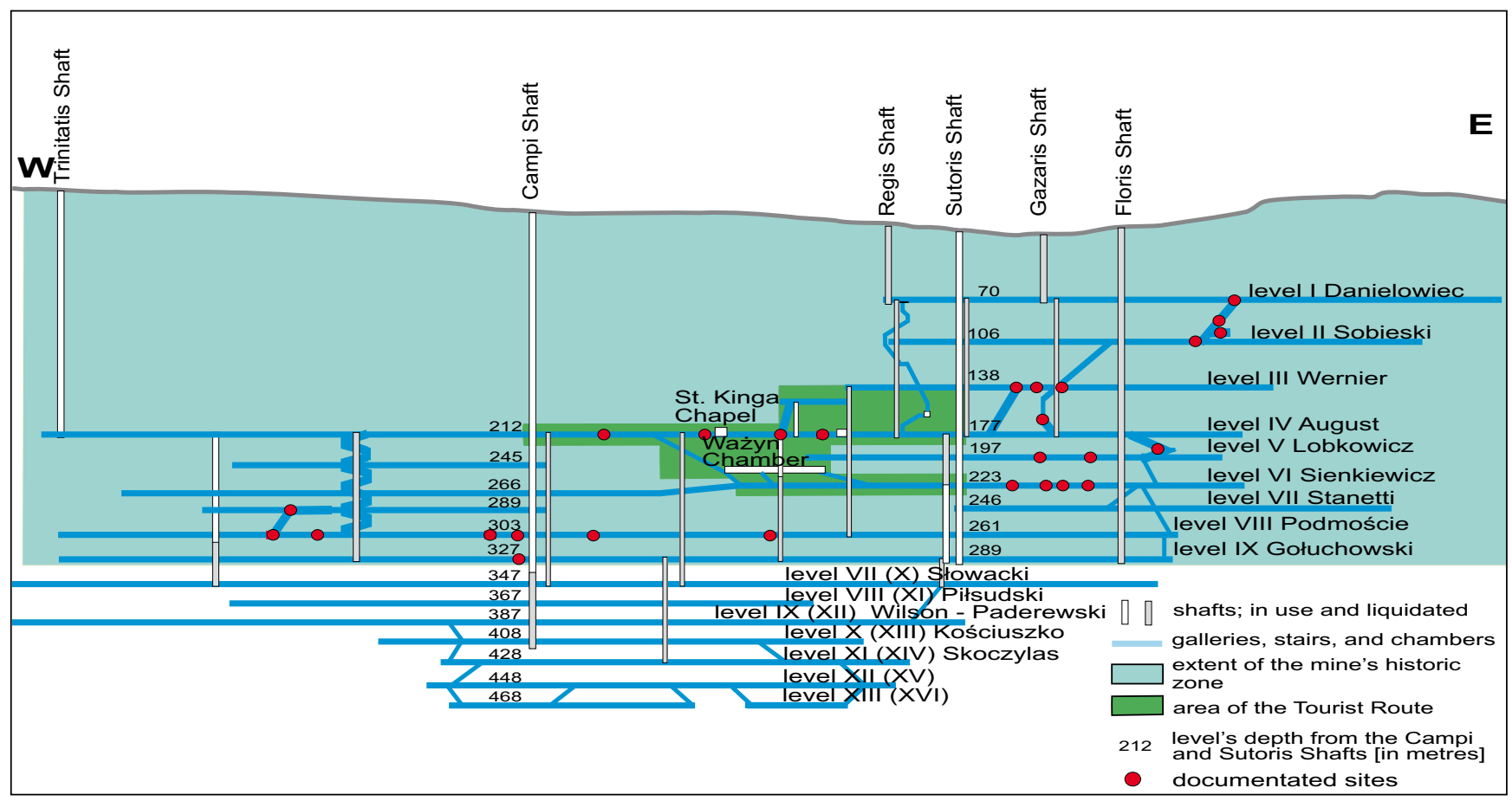

Fig. 9. Vertical sketch-map of the Bochnia Salt Mine with the documentated sites (after Charkot, 2005) • Pionowy szkic Kopalni Soli Bochnia ze stanowiskami dokumentacyjnymi (wg Charkot, 2005) 


\section{Protection of the natural and historic heritage}

Out of ca. 2350 exploitation chambers and $240 \mathrm{~km}$ of galleries dug in the Wieliczka deposit, a lot have been well preserved till recent times. They constitute the historic Wieliczka Salt Mine (Figs 5-7), written into the first UNESCO List of the World Natural and Cultural Heritage (1978) and recognised as a National Monument of History (1994). Due to the initiative of the Department of the Environmental Protection of the voivode office in Kraków, the sites important for geology of the deposit were chosen and documented with detailed descriptions, sketches, photographs, and information tables. From 1992, a specialist staff directed by the mining geologist, Janusz Wiewiórka, worked out 40 documentated sites within the Tourist Route, including the underground exhibition of the Kraków Saltworks Museum, as well as the galleries leading to and surrounding the Crystal Caves. In 2000 the Natural Reserve "Crystal Caves" (Fig. 8) in Wieliczka was approved by the Małopolska voivode. Touring the documentated sites situated outside the Tourist Route and the Museum exhibition is possible after previous notification in the Tourist Office of the Wieliczka Salt Mine.

In 1990, having ended the exploitation of the rock salt, the Bochnia Salt Mine was liquidated. Earlier (1981) a decision of the conservation office in Tarnów, after recognising the six oldest levels of the Bochnia Salt Mine (Fig. 9) as a historic monument, opened the way for preserving its most precious underground excavations and surface devices. The galleries below the ninth level ( $289 \mathrm{~m})$, however, have been closed down and successively backfilled. In selected sites of the higher levels, the adaptation works unveiled already illegible geological structures and remains of historic excavations, often backfilled, without disturbing the stability of the rocks masses. In 1995 a new period of activity of the mine commenced, focused on the tourism, recreation, and health care. The position of the mine as a historic object, to be protected, was strengthened by legal documents; the Decree of the President of the Republic of Poland recognizing the Bochnia Salt Mine as a National Monument of History (2000), and the Decree of the Małopolska voivode (2005) approving 27 documentated sites (Figs 10, 11). Beside standard tours and recreation and health underground stays, geological tours are also possible, under supervision of a competent mining staff. At present efforts are made for putting the Bochnia Salt Mine on the UNESCO List of the World Cultural and Natural Heritage.

\section{Concluding remarks}

Apart from routine mining works, backfilling and securing the excavations, the appropriate preservation of the cultural and natural heritage of the Wieliczka and Bochnia Salt Mines requires specialist works under a strict conservator's supervision. It is of particular importance in cases of objects important for the natural heritage, preserved in the rock-salt deposits. In the authors' opinions, essential here is a continuous conservator's

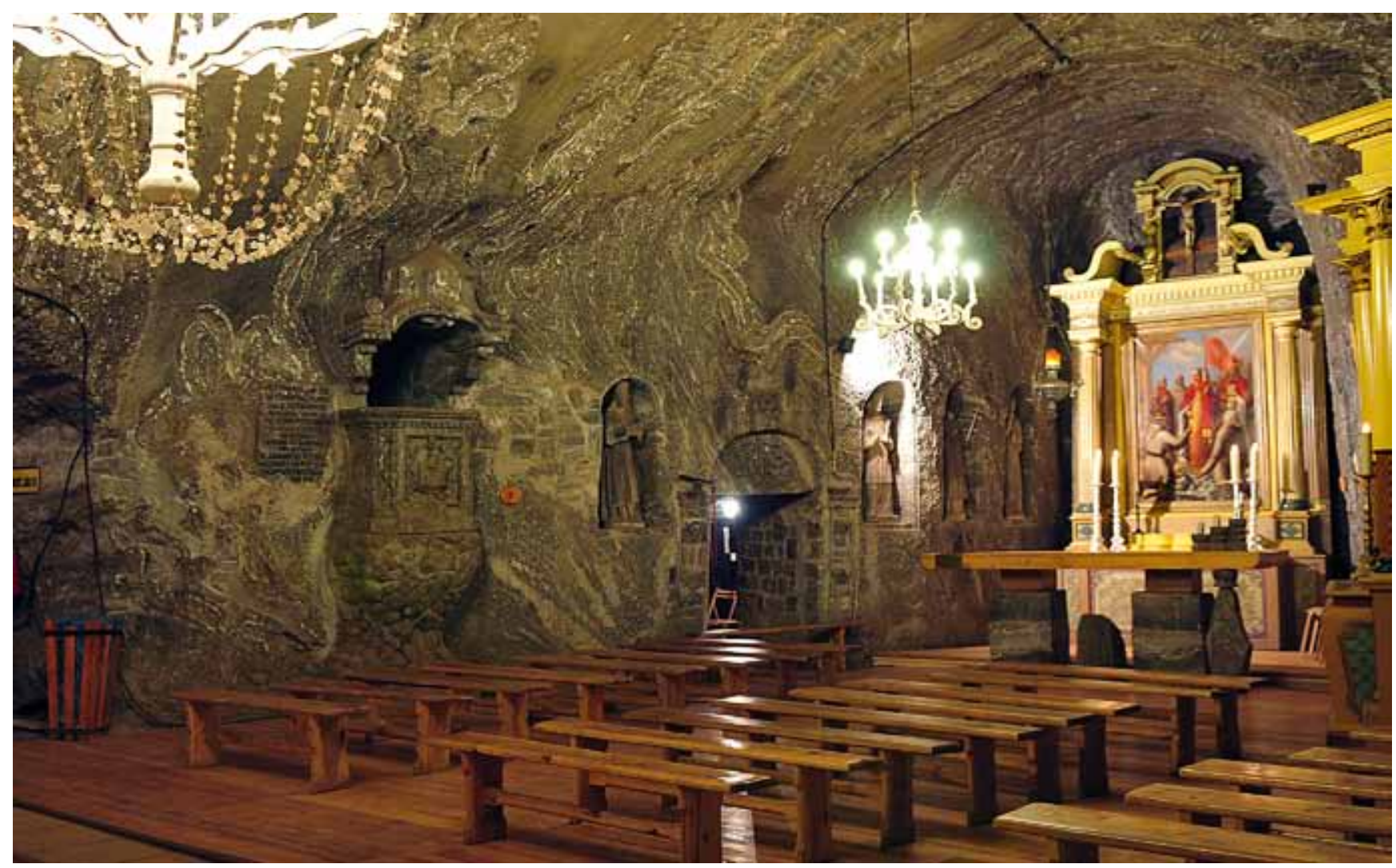

Fig. 10. St. Kinga Chapel in the Bochnia Salt Mine. In the walls and top folded strata of northern salts and clays with anhydrite. Phot. Archives of Bochnia Salt Mine • Kaplica Św. Kingi w Kopalni Soli Bochnia. W ścianach i stropie zafałdowane warstwy soli północnych i iłowca z anhydrytem. Zdjęcie z Archiwum Kopalni Soli Bochnia 
supervision, exercised by the staff independent of the institutions managing the underground objects. Above all, the documentated sites, which include the salt-deposit geology and larger-scale events, such as folding and overthrusting of the Outer Carpathians, require such a supervision. In the walls of the galleries and chambers not only are lithostratigraphical

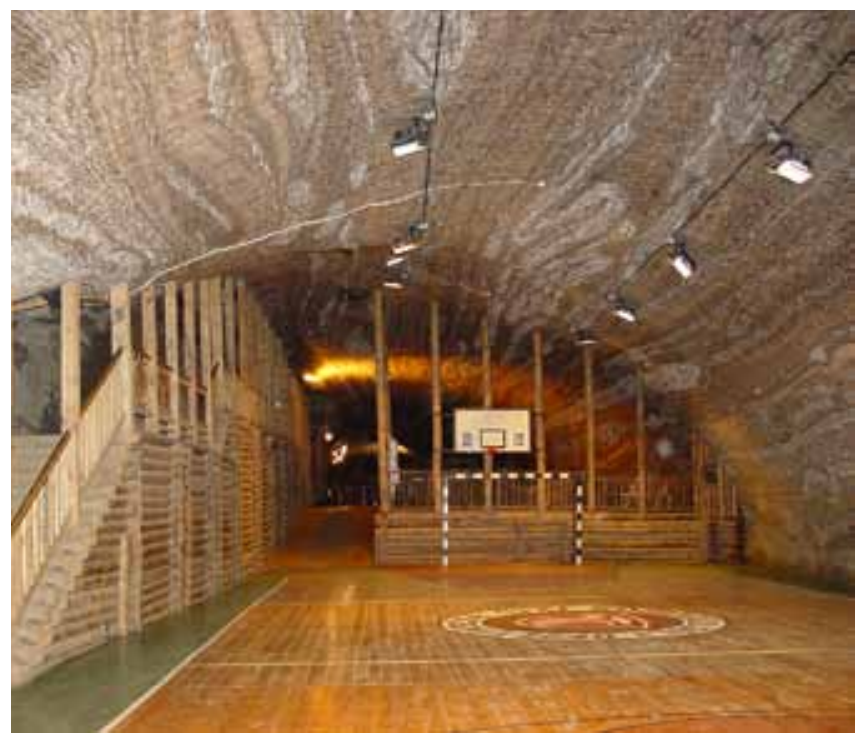

Fig. 11. Ważyn Chamber in the Bochnia Salt Mine. Phot. Archives of Bochnia Salt Mine • Komora Ważyn w Kopalni Soli Bochnia Fot. z Archiwum Kopalni Soli Bochnia

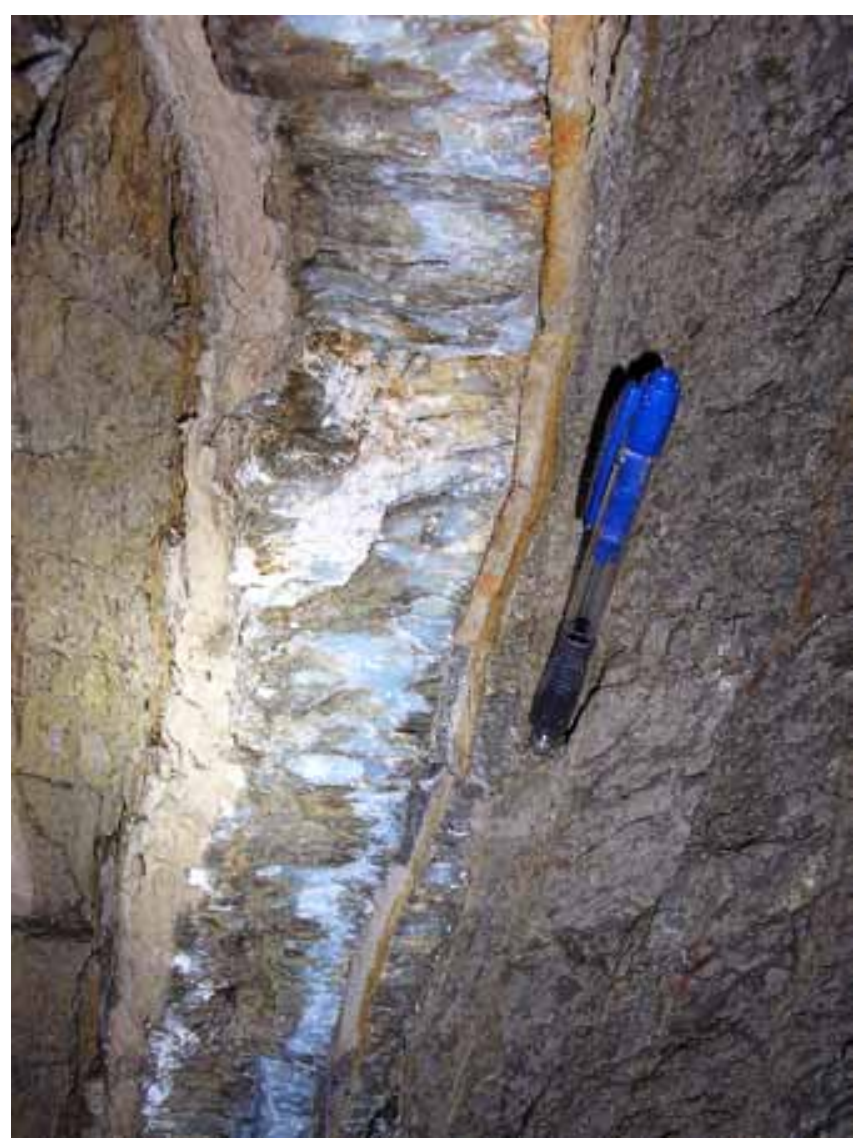

Fig, 12. Tuff layer WT-2 in clays with anhydrite in perpendicular gallery August, Bochnia Salt Mine. Phot. K. Dudek - Wkładka tufitowa WT-2 w iłowcu z anhydrytem w poprzeczniku August, Kopalnia Soli Bochnia. Fot. K. Dudek sequences of the rocks forming the deposits (Wieliczka Formation) preserved, but also relationships with the lower (Skawina Formation) and the upper (Chodenice beds) complexes. In a situation, when many surface outcrops of the Badenian salt-bearing complex disappeared in a natural way or through the deliberate recultivation works, only the preserved underground excavations enable one to study the profile and relationships between its individual elements.

Some outcrops enable studies on the salt crystallization processes in the evaporite basin and later transformations, and are particularly valuable for studies on formation of the salt deposits in the Carpathian Foredeep. Terrigenous sediments often contain abundant accumulations of carbonised plants, whereas the tuff layers (Fig. 12) prove extensive volcanic activity in the neighbouring Carpathians. Microfossils of the Skawina Formation and the Chodenice beds, as well as macrofossils deposited in the rock salts, in particular in the spiza salts in Wieliczka, document the high variability of the environmental conditions in the evaporite basin.

The exceptional complexity of conditions of formation of the Wieliczka and Bochnia deposits confirms facies diversity and subsequent tectonic processes. Attention should be also paid to the objects, preserved in the mines, which point out Pleistocene and recent processes. Protection of the Crystal Caves in Wieliczka, and the sites of occurrence of the visceral, enterolithic anhydrite in Bochnia (Fig. 13), is necessary for studies on more recent history of the deposit. The outcrops of salt containing condensed methane accumulations (banging salt) and sites in which fine crystals and mineral crusts (Figs $14,15)$ grow due to salt-water leaks should also be protected. It is our duty to preserve for future generations as much as possible of the Earth's history written in the dark galleries and chambers of the Wieliczka and Bochnia Salt Mines.

Acknowledgements. Mark Pawlewicz of the U.S. Geological Survey in Denver is kindly acknowledged for the linguistic correction of the text. The study was partly financed by WGGiOŚ AGH, grant No. 11.11.140.158. $\square$

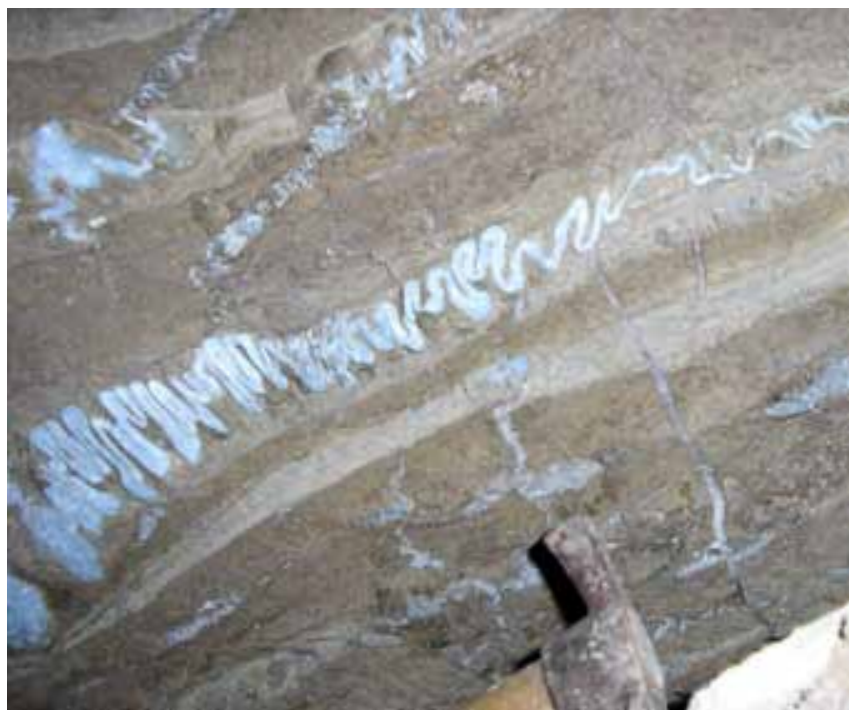

Fig. 13. Enterolithic anhydrite in clays in the perpendicular August gallery, Bochnia Salt Mine Phot. K. Dudek - Anhydryt trzewiowy w iłowcu z anhydrytem w poprzeczniku August, Kopalnia Soli Bochnia. Fot. K. Dudek 


\section{Streszczenie}

\section{Zabytkowe kopalnie soli w Wieliczce i Bochni}

\section{Janusz Wiewiórka, Józef Charkot, Krzysztof Dudek \& Malgorzata Gonera}

Zabytkowe kopalnie soli w Wieliczce i Bochni znajduja się przy starym szlaku handlowym wiodącym z Krakowa na wschód - na Ukrainę (Fig. 1), w regionie znanym z warzenia soli jeszcze w neolicie (3500 lat p.n.e.). Odkrycia soli kamiennej w Bochni dokonano w 1248 roku, pięć lat przed założeniem miasta. Eksploatacja soli kamiennej w Wieliczce była potwierdzona w dokumencie lokacyjnym miasta z 1290 roku. Od końca XIII wieku kopalnie te tworzyły jedno przedsiębiorstwo - Krakowskie Żupy Solne. W XVI wieku zatrudniało ono ok. 2000 ludzi i było największym zakładem produkcyjnym w Polsce, a zarazem jednym z największych w Europie. Ponad 700-letni okres eksploatacji soli kamiennej dobiegł końca w Bochni w 1990, a w Wieliczce w 1996 roku.

Obydwa złoża soli kamiennej znajdują się w sfałdowanych utworach miocenu (baden - M4) jednostki zgłobickiej, u czoła nasunięcia Karpat. Wśród nich wyróżnia się formację skawińską (podsolną), formację z Wieliczki (seria solna) i warstwy chodenickie (nadsolne). Unikalne w skali światowej złoże Wieliczki (Fig. 2, 3) składa się z dwóch części: górnego złoża bryłowego i dolnego złoża pokładowego. Powstanie złoża bryłowego wiąże się ze spływami podmorskimi w południowej części mioceńskiego zbiornika sedymentacyjnego. Zarówno złoże bryłowe, jak i pokładowe, zostały ostatecznie ukształtowane w wyniku ruchów nasuwczych Karpat zewnętrznych. Odmiennie wykształcone złoże Bochni (Fig. 3, 4) jest usytuowane w północnym, prawie pionowo zapadającym skrzydle fałdu bocheńskiego, znajdującego się na północ od brzegu nasunięcia karpackiego.

Relacje J. von Watta (Vadianus) z 1518 i J.-E. Guettarda z 1764 roku potwierdzają, że kopalnie te były szeroko znane już w tamtych czasach. Szczególne zainteresowanie budziła Wieliczka; położona bliżej Krakowa i posiadająca wielkie wyrobiska komorowe, która już w końcu XVIII wieku była uznaną atrakcją turystyczną. W 1978 roku Kopalnia Soli Wieliczka (Fig. 5-8) została wpisana na pierwszą listę Światowego Dziedzictwa Kulturowego i Przyrodniczego UNESCO, a w 1994 roku uznana za Narodowy Pomnik Historii. W 1981 roku zabytkowa część Kopalni Soli Bochnia (Fig. 9-12) została wpisana do rejestru zabytków ówczesnego województwa tarnowskiego, a w 2000 roku uznana za Narodowy Pomnik Historii. W ostatnich latach w obydwu kopalniach wyznaczono stanowiska dokumentacyjne przyrody nieożywionej, prawnie chronione dekretami Wojewody Małopolskiego. Stanowiska te dokumentują wszystkie elementy litostratygraficzne serii solnej, ich kontakt z utworami formacji skawińskiej i warstw chodenickich, a także unikalne niekiedy zjawiska tektoniczne. Dla zachowania dziedzictwa kulturowego i przyrodniczego kopalń soli w Wieliczce i Bochni konieczne są dalsze prace prowadzone pod ścisłym nadzorem konserwatorskim, szczególnie potrzebnym wobec

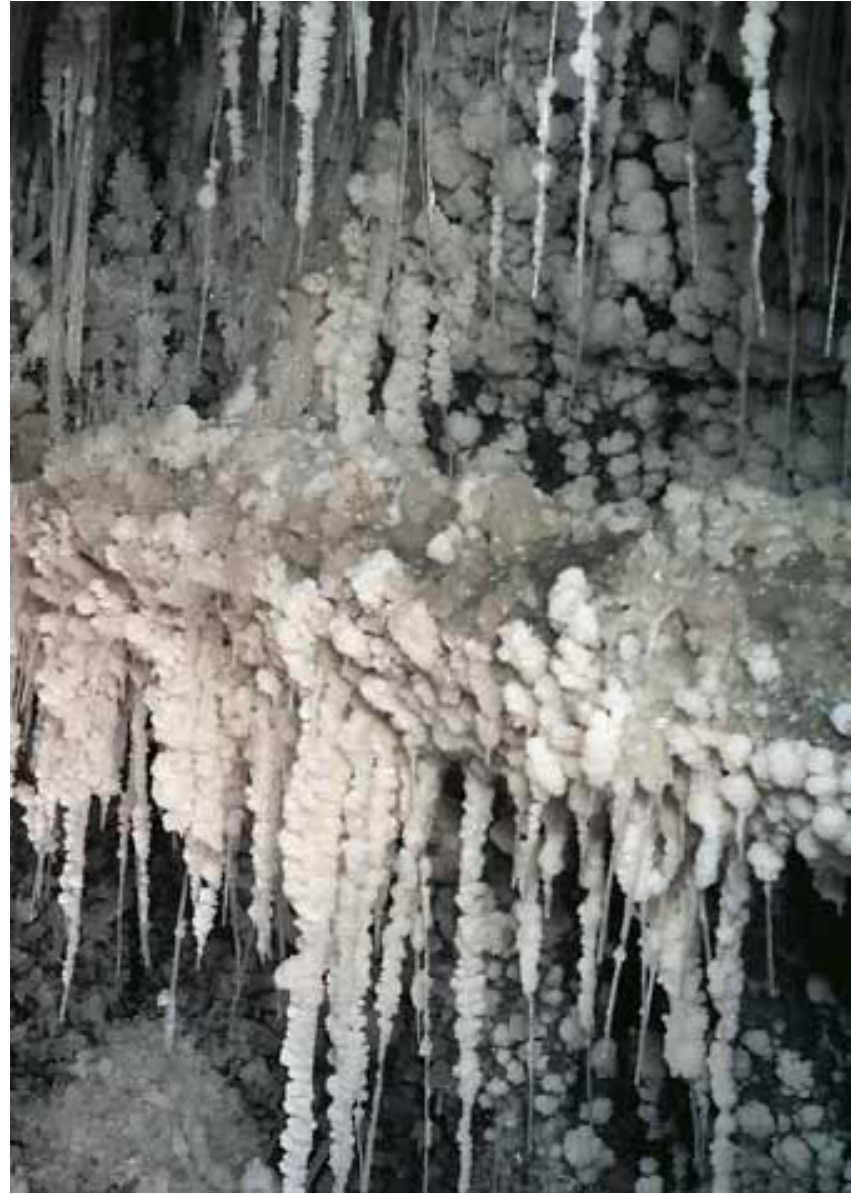

Fig. 14. Secondary halite covers and stalactites in the Ferro Chamber, Wieliczka Salt Mine. Phot. A. Grzybowski • Nacieki i stalaktyty wtórnego halitu w komorze Ferro, Kopalnia Soli Wieliczka. Fot. A. Grzybowski

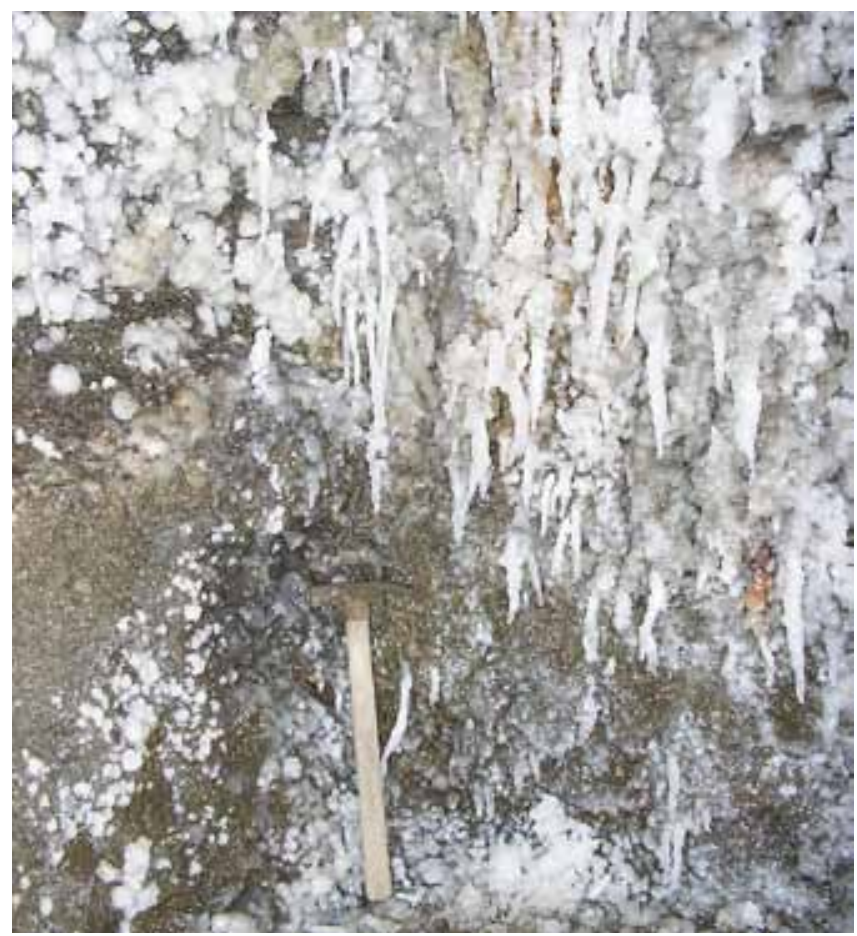

Fig. 15. Secondary halite covers and stalactites in the Gazaris II shaft in the Bochnia Salt Mine. Phot. J. Wiewiórka • Nacieki i stalaktyty wtórnego halitu w szybiku Gazaris II, Kopalnia Soli Bochnia. Fot. J. Wiewiórka 
obiektów mających znaczenie dla dziedzictwa przyrodniczego, utrwalonego w złożach soli kamiennej. W sytuacji, gdy w sposób naturalny lub przez rekultywację przestały istnieć powierzchniowe odsłonięcia badeńskiej serii solonośnej, pozostały już tylko wyrobiska podziemne. Takie stanowiska jak Groty Kryształowe w Wieliczce i miejsca występowania anhydrytu trzewiowego w Bochni (Fig. 13), znakomicie ilustrują procesy krystalizacji minerałów. Ochrony wymagają również miejsca występowania soli zawierającej nagromadzenia me- tanu (sól trzaskająca) oraz miejsca, gdzie na skutek wycieków zasolonych wód tworzą się piękne kryształy i formy naciekowe (Fig. 14, 15). Odsłonięcia geologiczne w historycznych wyrobiskach są jak otwarte karty historii Ziemi, fascynujące nie tylko geologów i studentów, ale również setki tysięcy turystów. Kopalnie soli w Wieliczce i Bochni są ważnym elementem planowanej ukraińsko-polskiej trasy geoturystycznej „Śladami olbrzymich wymarłych ssaków, wosku ziemnego, ropy naftowej i soli”, przebiegającej od Staruni do Krakowa.

\section{References (Literatura)}

Alexandrowicz, S.W., Garlicki, A. \& Rutkowski, J., 1982. Podstawowe jednostki litostratygraficzne miocenu zapadliska przedkarpackiego. Kwartalnik Geologiczny, 26 (2): 470-471 (In Polish only).

Andreyeva-Grigorovich, A.S., Oszczypko, N., Savitskaya, N.A., Ślączka, A. \& Trofimovich, N.A., 2003. Correlation of Late Badenian salts of the Wieliczka, Bochnia and Kalush areas (Polish and Ukrainian Carpathian Foredeep. Annales Societatis Geologorum Poloniae, 73: 67-89.

Bukowski, K., 1999. Comparison of the Badenian saliferous series from Wieliczka and Bochnia in the light of new data. Prace Państwowego Instytutu Geologicznego, 168: 43-56 (In Polish, English summary).

Charkot, J., 2005. An outline of Bochnia Salt Mine space expansion 1772 1990. Studia i Materiały do Dziejów Żup Solnych w Polsce, 24: 25-58 (In Polish, English summary).

Charysz, J. \& Wiewiórka, J., 1976. Paleogeograficzne warunki sedymentacji ewaporatów w dolnej części złoża Wielickiego. Sprawozdania z Posiedzeń Komisji Naukowych PAN, Oddział w Krakowie, 20 (1): 197-199 (In Polish only).

Dudek, K., Bukowski, K. \& Heflik, W., 2004. Mineralogical characteristics of the Bochnia tuff from the Chodenice Beds (Carpathian Foredeep), S Poland. Mineralogia Polonica, 35 (2): 63-77.

Garlicki, A., 1968. Autochthonous salt series in the Miocene of the Carpathian Foredeep, between Skawina and Tarnów. Biuletyn Instytutu Geologicznego, 215: 5-77 (In Polish, English summary).

Garlicki, A., 1979. Sedimentation of Miocene salts in Poland. Prace Geologiczne PAN, 119: 1-67 (In Polish, English summary).

Garlicki, A., 1994. Formalne jednostki litostratygraficzne miocenu - formacja z Wieliczki (fm). Przegląd Geologiczny, 42 (1): 26-28 (In Polish only).

Garlicki, A., 2008. Salt Mines at Bochnia and Wieliczka. Przegląd Geologiczny, 56 (8/1): 663-669.

Gaweł, A., 1962. Geology of the Wieliczka salt deposit. Prace Instytutu Geologicznego, 30 (3): 305-327 (In Polish, English summary).

Gonera, M., 2001. Foraminifers and palaeoenvironment of the Badenian (Middle Miocene) Formation in the area of the Upper Silesia. Studia Naturae, 48: 5-211 (In Polish, English summary).

Jodłowski, A., Wiewiórka, J., Piotrowicz, J., Keckowa, A., Dziwik, K. \& Wyrozumski, J., 1988. The history of Kraków Salt-Works. Muzeum Żup Krakowskich Wieliczka, 460 pp. (In Polish, English summary).

Kolasa, K. \& Ślączka, A., 1985a. Sedimentary salt megabreccias exposed in the Wieliczka mine Fore-Carpathian Depression. Acta Geologica Polonica, 35 (3-4): 221-230.

Kolasa, K. \& Ślączka, A., 1985b. Some remarks on the Wieliczka salt deposit genesis. Studia i Materiały do Dziejów Żup Solnych w Polsce, 14: 7-49 (In Polish, English summary).

Kotarba, M.J., 2009. The Starunia palaeontological site and idea of Ukrainian-Polish trans-border geoturist trail "Traces of large, extinct mammals, earth wax, oil and salt: from Starunia to Kraków". Geoturystyka, This volume.
Oszczypko, N., 1996. The Miocene dynamics of the Carpathian Foredeep in Poland. Przegląd Geologiczny, 44 (10): 1007-1018 (In Polish, English summary).

Oszczypko, N., 1997. The Early-Middle Miocene Carpathian peripheral foreland basin (Western Carpathians, Poland). Przegląd Geologiczny, 45 (10/2): 1054-1063.

Oszczypko, N., Krzywiec, P., Popadyuk, I. \& Peryt, T., 2006. Carpathian Foredeep Basin (Poland and Ukraine): its sedimentary, structural, and geodynamic evolution. In: Golonka, J. \& Picha, F.J. (Eds.), The Carpathians and their foreland: Geology and hydrocarbon resources. American Association of Petroleum Geologists, Memorie, 84: 293-350.

Parachoniak, W., 1962. Miocene pyroclastic deposits on the foreland of the Polish Carpathians. Prace Geologiczne Komisji Nauk Geologicznych PAN Oddz. w Krakowie. 11: 7-77 (In Polish, English summary).

Poborski, J., 1952. The Bochnia salt deposit on the geological background of region. Biuletyn Państwowego Instytutu Geologicznego, 78: 3-160 (In Polish, English summary).

Smaroń, A., 1982. Two oldest latin reports on Kraków Salt-Works. Studia i Materiały do Dziejów Żup Solnych w Polsce, 11: 117-157 (In Polish, English summary).

Tarkowski, R., 2005. Nowe materiały dotyczace podróży przyrodnika francuskiego J.-E. Guettarda do Polski (1760-1762). Przegląd Geologiczny, 53 (1): 41-46 (In Polish only).

Wiewiórka, J., 1974. Level of the oldest rock-salt in the stratified salt deposit of Wieliczka. Studia i Materiały do Dziejów Żup Solnych w Polsce, 3: 17-38 (In Polish, English summary).

Wiewiórka, J., 1979. Przewodnie poziomy tufitowe w kopalni soli Wieliczka. Sprawozdania z Posiedzeń Komisji Naukowych PAN, Oddział w Krakowie, 21 (1): 176-178 (In Polish only).

Wiewiórka, J., 1988. Geological conditions of salt exploitation in the Kraków Salt-Works. In: Jodłowski, A., Wiewiórka, J., Piotrowicz, J., Keckowa, A., Dziwik, K. \& Wyrozumski, J. The history of Kraków Salt-Works. Muzeum Żup Krakowskich Wieliczka, 37-70. (In Polish, English summary).

Wiewiórka, J., Charkot, J., Dudek, K. \& Gonera M., 2007. New data on the salt-deposit geology and the mining history in the Bochnia Salt Mine. Gospodarka Surowcami Mineralnymi, 23, special volume 1: 157-162 (In Polish, English summary).

Wiewiórka, J., Dudek, K., Charkot, J. \& Gonera M., 2009. Natural and historic heritage of the Bochnia salt mine (South Poland). Studia Universitatis Babes-Bolyai, Geologia, 54 (1): 43-47.

Wójcik, Z., 1977. The origin of rock salt and the methods of its exploration as viewed by Jean Etienne Guettard. Prace Muzeum Ziemi, 27: 3-25 (In Polish, English summary).

\section{Web sites}

www.kopalnia-wieliczka.pl

www.muzeum.wieliczka.pl/

www.kopalniasoli.pl/ 